\section{The Next Ten Years: Strategic Vision of Water Resources for Nursery Producers}

\author{
Amy Fulcher ${ }^{1,6}$, Anthony V. LeBude ${ }^{2,6}$, James S. Owen, Jr. ${ }^{3,6}$, \\ Sarah A. White ${ }^{4,6}$, and Richard C. Beeson ${ }^{5}$
}

AdDITIONAL INDEX WORDs. conservation, drought, irrigation, policy, regulation, technology, water recycling

Summary. Nursery and greenhouse producers, research and extension faculty, and representatives from allied fields collaborated to formulate a renewed vision to address water issues affecting growers over the next 10 years. The authors maintained the original container irrigation perspective published in "Strategic vision of container nursery irrigation in the next ten years," yet broadened the perspective to include additional challenges that face nursery crop producers today and in the future. Water availability, quality, and related issues continue to garner widespread attention. Irrigation practices remain largely unchanged due to existing irrigation system infrastructure and minimal changes in state and federal regulations. Recent concerns over urbanization and population growth, increased climate variability, and advancements in state and federal regulations, including new groundwater withdrawal limitations, have provided an inducement for growers to adopt efficient and innovative practices. Information in support of the overarching issues and projected outcomes are discussed within.

$\mathrm{N}$ ursery crops research and extension faculty from the southeastern and mid-Atlantic United States, in collaboration with the Horticultural Research Institute

Funding for this work was provided, in part, by the Florida, North Carolina, South Carolina, Tennessee, and Virginia Agricultural Experiment Stations, Agriculture Research Services, and the Hatch Programs of the National Institute of Food and Agriculture, U.S. Department of Agriculture, including work under award numbers 2014-51181-22372 and 2014-51130-22493.

Craig Regelbrugge, John Majsztrik, and Jeb S. Fields are gratefully acknowledged for reviewing internal drafts of the manuscript.

Any opinions, findings, conclusions, or recommendations expressed in this publication are those of the author(s) and do not necessarily reflect the view of the U.S. Department of Agriculture, land grant institutions, or universities.

Fulcher, A., A.V. LeBude, J.S. Owen, Jr., and S.A. White contributed equally to this work.

${ }^{1}$ Assistant Professor, Department of Plant Sciences, University of Tennessee, 2431 Joe Johnson Drive, Ellington Plant Science Building, Room 252, Knoxville, TN 37996

${ }^{2}$ Associate Professor, Horticultural Science, Mountain Horticultural Crops, Research \& Extension Center, 455 Research Drive, Mills River, NC 28759

${ }^{3}$ Assistant Professor, Department of Horticulture, Virginia Tech, Hampton Roads Agricultural Research and Extension Center, Virginia Beach, VA 23455

${ }^{4}$ Associate Professor, Department of Agricultural \& Environmental Sciences, Clemson University, E-143 Poole Agricultural Center, Clemson, SC 29634

${ }^{5}$ Professor, Environmental Horticulture, Mid-Florida Research and Education Center, 2725 S. Binion Road, Apopka, FL 32703

${ }^{6}$ Corresponding authors. E-mail: afulcher@utk.edu, anthony_lebude@ncsu.edu, jsowen@vt.edu, and swhite4@ clemson.edu.

This is an open access article distributed under the CC BY-NC-ND license (http://creativecommons.org/ licenses/by-nc-nd/4.0/).
(Washington, DC), undertook the task of updating the seminal paper "Strategic vision of container nursery irrigation in the next ten years" by Beeson et al. (2004). The perspectives, inherent in that important paper, are foundational for exploring the challenges that lie ahead. Therefore, the aim of this paper is to reflect on the predictions and conclusions of Beeson et al. and discuss their relevance to today's nursery and greenhouse industries. The current authors surveyed informally over 50 nursery and floriculture producers, academic faculty, extension professionals, and allied industry supporters to compare the original 10 -year strategic plan published by Beeson et al. (2004) with events that occurred over that 10 -year period, and have formed

\section{Revisiting predictions of the past decade (2005 to 2015)}

The consensus of Beeson et al. (2004) was that the availability and a strategic vision for the next 10 years. consumption of both ground and surface waters by container nurseries would decline in the coming decade (2005-15). In general, water availability would diminish either because of competition with urban areas (e.g., population increase coupled with urbanization), direct and indirect effects of drought, decrease in water quality, or regulations limiting withdrawals. In addition, nurseries would adopt technologies and cultural practices to consume the remaining available water more efficiently, therefore, using less water to produce the same quantity and quality of plant material. For the remainder of this article, major points and predictions by Beeson et al. (2004) are denoted as subheadings, followed by an assessment of those major points. A concluding section provides predictions for the next 10 years.

\section{Water availability and quality}

AvaILABILITY AND CONSUMPTION FROM GROUNDWATER OR PUBLIC SURFACE WATERS BY CONTAINER NURSERIES WILL DECLINE SIGNIFICANTLY IN THE COMING DECADE. Although there are fewer horticultural operations, overall, they are consuming substantially more water and increasingly reliant on groundwater. This is, in part, because of significant drought in the western United States, which not only increases the need for irrigation because of lack of precipitation, but also diminishes surface water reserves. Between 2008 and 2013, there were 2\% fewer irrigated nursery crop operations on $13 \%$ fewer acres, yet irrigated acreage increased $\approx 2 \%$ for nurseries classified as in the open and not covered [U.S. Department of Agriculture (USDA), 2014; Table 4l]. For all open area, irrigated horticultural operations (including nursery crops) during that same time, there were $14 \%$ fewer horticultural operations; yet, of those

\begin{tabular}{lllc}
\hline $\begin{array}{l}\text { Units } \\
\text { To convert U.S. to SI, } \\
\text { multiply by }\end{array}$ & U.S. unit & SI unit & $\begin{array}{l}\text { To convert SI to U.S., } \\
\text { multiply by }\end{array}$ \\
\hline 0.4047 & acre $(\mathrm{s})$ & $\mathrm{ha}$ & 2.4711 \\
102.7902 & acre-inch(es) & $\mathrm{m}^{3}$ & 0.0097 \\
0.0283 & $\mathrm{ft}^{3}$ & $\mathrm{~m}^{3}$ & 35.3147 \\
3.7854 & gal & $\mathrm{L}$ & 0.2642 \\
9.3540 & gal/acre & ${\mathrm{L} \cdot h a^{-1}}^{3}$ & 0.1069 \\
0.9072 & ton(s) & tonne(s) & 1.1023
\end{tabular}


that remained in $2013,12 \%$ more groundwater (about 15 trillion gal) was applied (USDA, 2014; Table 43). In 2013, these same horticultural operations applied $43 \%$ less volume ( 22 billion gal fewer) from on-farm surface water and $\approx 5 \%$ more volume ( 2.5 billion gal) from off-farm water sources [e.g., irrigation districts, commercial companies, municipal reclaimed water $(\mathrm{mRCW})$ sources, or community water systems] (USDA, 2014; Table 43). A similar survey of production and marketing practices of the green industry in 2013 contrasts slightly with the results above for water use in the past 5 years. About $65 \%$ of grower firms indicated using the same amount of water, $10 \%$ used more, and $25 \%$ used less water per acre (Hodges et al., 2015). Irrigation water sources, however, were similar in that $65 \%$ reported using groundwater wells and $32 \%$ surface water, whereas a lower share used city water $(19 \%)$ as an irrigation source (respondents were allowed to choose more than one water source, thus percentages do not equal 100) (Hodges et al., 2015). Taken together, this overall increase in per operation consumption reflects a growing dependence on groundwater, particularly during drought.

Based on predominant irrigation practices at container nurseries, water consumption on a per acre basis has not declined since 2004. Some growers are recording volumes used per year to substantiate water needs for continued production of crops in the case of water restrictions. However, the volume of water used for irrigation by U.S. nurseries on a day-to-day basis remains poorly quantified by most growers. In a 2012 survey of water use by nursery growers in the United States ( $J$. Majsztrik, personal communication), most respondents (85\%) did not answer the question "How much water do you apply on a yearly basis?" Of those who responded, water use ranged from 2381 to $5,850,000 \mathrm{gal} / \mathrm{acre} /$ year. This range is striking in that 1 acre-inch of water is equal to $\approx 27,000$ gal, which equates to $\approx 5$ to 6 million gal/acre/year for many growers irrigating 1 inch per day between 160 and $200 \mathrm{~d}$ per year. This range potentially demonstrates the difficulty producers have at estimating annual water use in the absence of flow meters. Measuring and recording monthly or annual water usage is critical to future water security, thus nursery crop producers should invest in needed technology, keep accurate records, and train personnel.

In the next decade, it does not appear that nursery crop producers collectively will consume less water per acre voluntarily. More likely, state regulatory agencies will require nursery crop producers to report annual water withdrawals, regardless of quantity applied or source (surface or groundwater). Producers in some eastern states, which are under riparian water rights law, are required to report usages if volumes applied reach a critical threshold. For example, reporting is required if volumes withdrawn exceed 1 million gal per any $\mathrm{l} \mathrm{d}$ of irrigation in North Carolina (State of North Carolina, 2008), exceed 1 million gal in any 1 month in Virginia (Commonwealth of Virginia, 2015), exceed 3 million gal of surface water in any 1 month for new permits issued in South Carolina (State of South Carolina, 2014), or average of 100,000 gal of water per day in any consecutive $30-\mathrm{d}$ period in Michigan (State of Michigan, 2003). In addition, in Michigan, registered users must submit a water conservation plan with applicable management practices and disclose the location and baseline capacity of the withdrawal system if using groundwater (State of Michigan, 2006). In Tennessee, reasonable use is not defined, nor is there a use limit for agricultural users (Tenn. Code ann. \$ 68-221-702, 69-3-102, and 69-3-103; State of Tennessee, 2015).

Conversely, in western states, which adhere to prior appropriation rights, the volume of water available depends on the seniority of the user within the watershed, which typically favors agriculture over urban consumers since agriculture often has a prior claim. Nevertheless, environmental and urban population demands will also play a role in coming years as increasing challenges arise for water use and allocation. Since 2001, California has become increasingly dry (U.S. Drought Monitor, 2015) and in 2014 and $2015, \approx 25 \%$ to $100 \%$ of surface water allocations for farmers were unavailable because of both an ongoing drought and competition with senior water rights holders and urban centers. Restrictions have been imposed on urban water districts to decrease potable water usage $25 \%$ through Feb. 2016, yet districts supplying agriculture users must only create drought management plans for the water intended for growers (State of California, 2015). Without sufficient water to produce crops profitably, producers have purchased water from other suppliers (e.g., other agriculture users selling their appropriation volumes), intentionally fallowed acreage, switched production to crops with lower water requirements, or pursued nonagriculture employment (USDA, 2014; Table $5)$. Moreover, growers increasingly relied on wells, which are less tightly regulated for agriculture production, thus reducing groundwater reserves.

Groundwater withdrawals have increased over the past 10 years because of drought and diminishing surface water resources, especially in western U.S. states (Howitt et al., 2014; USDA, 2014; Wallander and Hand, 2011). Monetary incentives (e.g., Environmental Quality Incentives Program) to increase water conservation throughout the United States have aided in increasing irrigation application efficiency (e.g., variable speed pumps coupled with subsurface or drip irrigation) in existing and newly planted acreages. Since California state government incentives began in 1970, producers have increased production, using the same volume of water, by increasing use of low-volume irrigation methods and decreasing use of gravity-based and sprinkler head irrigation (Guo, 2015). However, water use remains unchanged in production areas with dated water application technologies or infrastructure, or where incentives are not offered.

Production costs increase as A RESULT OF NEW METHODS AND TECHNOLOGIES ADOPTED TO INCREASE WATER USE EFFICIENCY. The majority of growers we spoke to mentioned new sensor technologies as an opportunity to monitor the need to irrigate container-grown crops. Practitioner concerns with sensor technology are cost and reliability when used to monitor water 
availability in containers and then use that information to control irrigation decisions either automatically or with real-time grower feedback (Majsztrik et al., 2013). In addition to the costs of hardware and software for sensor technology, costs include labor and technical expertise to manage and troubleshoot the newly proven technologies. Sensors, probes, or any instrument necessary to measure crop water availability in a nursery setting needs to be robust, reliable, easy to use, and produce accurate information consistently displayed in a manner growers are accustomed to using, to help return on investments in the technology. Recently, a pilot program estimated annualized costs of $\$ 14,000$ per year to adopt an enterprisewide irrigation monitoring and control sensor network that returns its investment in as little as 2.7 years in areas with low water costs and 4 months where water is more expensive (Belayneh et al., 2013).

A national survey of nursery crops producers in the United States reported that a large majority of growers perceived that wireless sensor networks would increase efficiency, increase plant quality, reduce product loss, and reduce irrigation management even though they were not familiar with the technology (Majsztrik et al., 2013). Adoption and retention of wireless sensor network technology by growers will rely on the ability of research and extension faculty, as well as allied suppliers, to articulate the abstract value of reduced production costs including value-added benefits (e.g., reduced disease incidence, shorter production times, and fewer management hours required) (Belayneh et al., 2013; Chappell et al., 2013) into a more understandable metric. Currently, research groups are working with innovative growers around the southeast to install these systems within nurseries and provide a local laboratory for other growers to observe firsthand the benefits of irrigation management technology. Adoption of irrigation technology is greater in regions where groundwater is saline, necessitating use of municipal water as the primary water source such as Oklahoma (Hodges et al., 2015; S. Taghvaeian, personal communication). The real costs (direct and indirect) of production associated with long-term implementation and maintenance of technologies nursery-wide are yet to be realized, as is the actual savings on a nursery-wide scale when the appropriate amount of sensors and networking are installed and additional species are evaluated.

One complication of calculating accurate return on investment is that the true cost of water as a limited resource is not assessed to users, regardless of source. Policy makers and water consumers ignore the true costs of using water, excluding costs such as ground subsidence from excessive pumping, ecological damage caused by low base water flows or impaired quality, and maintenance of municipal water delivery and treatment. Excessive groundwater extraction can cause overdraft, failed wells, deteriorated water quality, environmental damage, and irreversible land subsidence that damages infrastructure and diminishes the capacity of aquifers to store water for the future. The true cost, if accounted for, would increase the price of water, likely driving adoption of water-conservation practices.

Potable Water USE for NURSERY IRRIGATION DECLINES DURING DROUGHT AND AS A RESULT OF LEGISLATION. Beeson et al. (2004) referred to the use of municipally treated water for irrigating nursery and greenhouse crops when discussing a decline in potable water use for nursery irrigation. All water sources, with the exception of recycled (water stored in a pond or detention basin that has been used for irrigation already) and $\mathrm{mRCW}$, are considered potable for our discussions.

Water withdrawal permits issued in Florida have an allocation volume based on acreage, plant taxa, soil, climate, adjacent environmental criteria, and irrigation system. Once the allocation volume is set, permitted users have the legal right to consume that volume. This process works similarly to prior appropriation, in that users must consume their annual allocation or risk a decreased allocation in the future. In Florida, no state issued call for reducing consumptive volumes for permit holders has occurred since 2004. To reduce use of potable water for irrigation, various water districts in Florida encourage use of alternative water sources before use of potable water for irrigation. Alternative sources include poor quality groundwater, stormwater, and mRCW. When an alternative water source (e.g., mRCW) becomes available nearby and meets the criteria of being environmentally, technically, and economically feasible, businesses are encouraged to adopt the technology (Southwest Florida Water District, unpublished data).

Permitted water withdrawals for most states were not reduced over the last 10 years except when faced with extreme drought (major crop losses; widespread water shortages, or restrictions). More permits have been issued for water withdrawal volumes, and many growers have registered their withdrawals as a result of legislation. Yet these permits do not regulate total volume of water withdrawn, rather they indicate a threshold for when a permit is required. During periods of drought in California (2012-14) and McMinnville, Warren County, TN (2007-08), the number of well permits applied for and granted increased (Sbranti, 2014; C. Maner, personal communication) underscoring the reliance on groundwater during water scarcity.

In California, groundwater withdrawals were not regulated until legislation was passed on 16 Sept. 2014,3 years into an unprecedented drought. This legislation allowed local agencies to tailor groundwater plans to regional economic and environmental needs (State of California, 2014a). In Oregon, Jeff Stone, Executive Director of Oregon Association of Nurseries, and colleagues indicated the number of water permits have "declined sharply in recent years" as a result of current over-appropriation of ground and surface water, presumed interconnectivity of ground and surface water of one mile or more, and need for environmental analysis before permits being granted. In Georgia, the exceptional drought of 2006-08 resulted in restricted use of municipal water, loss of 35,000 green industry jobs, and closure or bankruptcy of $43 \%$ of green industry companies (Thomas and Hall, 2010). Economic losses were estimated at $\$ 3.15$ billion in 2007 (Omahen, 2008). Some of this decline, in addition to exceptional drought, is likely attributable to the U.S. "Great Recession" experienced nationally between 
Dec. 2007 and Feb. 2009. The prevalence of water scarcity in recent years has resulted in the development of water shortage plans for drought stricken areas (e.g., Georgia in 200607; Georgia Department of Natural Resources, 2011). These plans primarily focus on increasing capacity in preparation for future water shortages; however, some nursery producers unable to increase capacity have identified low-profit crops that can be sacrificed first.

Applying the U.S. Geological Survey average per capita water consumption estimate of 89 gal per capita per day (GPCD; Kenny et al., 2009) to U.S. Census Bureau population projections (U.S. Census Bureau, 2012), the United States will use 12,431 billion more gal of water over the next decade (2015-24). Since 1995, the GPCD estimate has decreased by 15 gal (Maupin et al., 2014), which might alleviate some stress of increasing population coupled with uncertainty of altered or decreased precipitation in mid-latitude dry regions. Nevertheless, the GPCD is going to lead to an anticipated further increase in water scarcity and competition within the United States (Intergovernmental Panel on Climate Change, 2013).

WATER AVAILABILITY IS LIMITED By WATER QUality. Salt Water IN TRUSION LIM ITS WATER AVAILABILITY IN COASTAL AND ARID REGIONS. Saltwater intrusion has been reported in wells in many seacoast states as well as in 22 inland states (Fernandez, 2014). In some coastal cities, $50 \%$ (Hilton Head, SC) to $100 \%$ (Hallandale Beach, FL) of municipal wells have been closed because of saltwater intrusion, with potential in Hilton Head, SC to close the remaining wells by 2024 (Hilton Head Public Service District, 2014; Reid, 2011). In the Salinas Valley, $\mathrm{CA}$, some growers must blend an alternative water source (mRCW) with saline groundwater to have enough quality water to meet irrigation demands (Johnson, 2013); while in the Pajaro Valley, CA, continued overdraft of freshwater wells along the coast led to increasingly severe saltwater intrusion, and thus contamination of the groundwater used by many growers (Taylor, 2014). In Michigan, northern Indiana, and northeastern Illinois, high capacity wells (>70 gal $/ \mathrm{min}$ ) used for irrigation and other purposes are causing saltwater intrusion by upconing (pulling the denser salt water into fresh groundwater (Feinstein et al., 2010). Upconing has prompted floriculture producers in those areas to use municipal water sources, and it underscores that unsustainable withdrawals can occur in areas with ample annual rainfall and water storage capacity. Indirect contamination of groundwater sources can result from increased industrialization and urbanization (e.g., storage of salts, application of salts to roadways, and hydraulic fracturing); increased salinity levels in contaminated aquifers may make waters withdrawn harmful for production of nursery crops (R.T. Fernandez and M.R. Chappell, personal communication).

Competition among environmental, agricultural, industrial, and urban uses of potable and nonpotable water sources will continue to increase, with demand especially great in coastal cities and arid regions where population centers continue to grow. This increase in human demand for water could further restrict water resources for irrigation of agricultural crops, especially nursery crops, which can be viewed as nonessential by general citizens. Agricultural users will likely need to increase water storage capacity, adopt water conserving production practices, and alter plant selection to facilitate use of poorer quality water sources (e.g., recycled production wastewater and mRCW) for irrigation. This will require continued investment in quantifying ecosystem services and educating consumers, legislators, and stakeholders on the benefits of ecosystem services provided by nursery crops and adequately promoting changes in plant inventories to remain sustainable.

TREATMENT OF SOURCE WATER BY NURSERIES OR MUNICIPALITIES AFFECTS COST AND VOLUME OF WATER AVAILABLE TO NURSERIES FOR IRRIGATION. NURSERIES STORE AND RECYCLE WATER, INCREASING RISKS OF PATHOGEN INFESTATION, AGRICHEMICAL CONTAMINATION, AND TREATMENT COSTS. Treating water increases the cost of a water supply. Recent costs of water for some greenhouses and nurseries ranged from $\$ 0.02$ to $\$ 1.62$ per cubic meter (\$0.08-6.13 per $1000 \mathrm{gal})$, depending on water source and local costs (Belayneh et al., 2013; Raudales et al., 2014). Water treatment costs in greenhouse operations ranged from $\$ 0.02$ to $\$ 5.15$ per cubic meter (\$0.08-19.49 per $1000 \mathrm{gal})$ for chlorinebased treatments alone (Raudales et al., 2014). Some floriculture producers in the midwestern United States (Great Lakes) region have chosen to use pretreated municipal water to ensure consistent, pressurized, highquality water instead of investing in maintenance of on-site treatment of surface or groundwater. Midwestern U.S. (Great Lakes) growers may employ a well or other water supply as a backup source.

Irrigating with surface and recycled irrigation waters infested with waterborne pathogens (e.g., species of Phytophthora and Pythium) is commonly viewed as a mechanism by which crops can become infected (Hong et al., 2014). Recent research has begun to investigate this commonly held perception, with mixed results. Raudales et al. (2014) stated "the risk of waterborne pathogens has yet to be clearly quantified in the complex environment of commercial operations." Loyd et al. (2014) reported that irrigation water infested with Phytophthora species was not a primary source of infection for rhododendron (Rhododendron species) and japanese pieris (Pieris japon$i c a)$ trap plants over two seasons, even though these foliar pathogenic species were present in the source water.

Recycling production runoff from nursery and floriculture operations will likely become a more widespread practice for producers to reduce reliance on potable water sources. Accurate quantification of the risk of recycled water with regard to pathogens, salinity, and agrichemical toxicity, including plant growth regulators, will drive grower investment in infrastructure to contain and treat water. Concomitantly, accurate, reliable, and affordable real-time measurements of many water quality factors are essential for making timely and informed production management decisions. Improvements are needed in these technologies to easily obtain information, enhance grower interaction with data, and increase sensor longevity.

Water sources with declining quality (e.g., mRCW and recycled 
irrigation runoff) will be used for irrigated production as legislative mandates and infrastructure development facilitates the use of these resources. Use of alternative sources to augment current, municipal, or groundwater sources will likely progress to the degree that they become the primary sources of irrigation, with potable water sources serving as backup water supplies. Use of alternative water sources by container nursery growers in California and Florida is already a common practice (Parsons et al., 2010).

WATER AVAILABILITY FOR IRRIGATION IS LIMITED DURING D ROUGH T B Y EM ERG E N Y PREPAREDNESS PLANS GOVERNING WATER USE. In response to extreme and exceptional drought events that have occurred over prolonged periods or for a short duration (i.e., flash drought) in the past decade, many states and municipalities developed emergency management plans to regulate water use. These plans govern essential and nonessential uses of water. Cities and states differ in their classification of agricultural uses of water, including nurseries, as essential or nonessential, and these classifications change as severity of drought increases. Using the U.S. Drought Monitor (2014) classification scheme, it is likely that water restrictions would impact growers "minimally" with "severe drought" [D2 (crop losses likely, water shortages common, and water restrictions imposed)], "moderately" with "extreme drought" [D3 (major crop losses, widespread water shortages, or restrictions)], and "severely" at levels of "exceptional drought" [D4 (exceptional and widespread crop losses, shortages of water in reservoirs, streams, and wells creating water emergencies)]. In an informal survey in Tennessee in 2014, just $5 \%$ of nurseries responding said that they had a drought plan beyond ensuring an alternate source of water (Yeary et al., 2014). In the future, nurseries must develop drought plans to increase infrastructure to store water, identify alternate water sources for use during droughts, prioritize the order in which plants are watered, and also plan changes in inventory to less water-intensive crops (LeBude and Bilderback, 2007). For example, customer demand for drought-tolerant plants is driving increased production of low-water use plants in some regions within the United States (Ouellet, 2014).

\section{Laws and regulations}

LAWS AND REGULATIONS CURRENTLY LIMIT NURSERY WATER CONSUMPTION IN CALIFORNiA, Florida, North Carolina, Texas, AND OREgon AND ARE EXPECTED TO BECOME MORE STRINGENT. Water law [prior appropriation in western United States vs. reasonable use (riparian) laws in eastern United States] has been and may continue to be modified in the face of changing water availability, affecting how uses are prioritized. In Texas (2012) and California (2013-14), agricultural user access to surface water was reduced or nonexistent during extended droughts. In 2014, for the first time in California history, groundwater extraction from aquifers was regulated (State of California, 2014b). Georgia legislators are developing revised drought management and water use efficiency rules (State of Georgia, 2014). In eastern states, regulations have not been passed to limit water withdrawals during drought or where land subsidence is of concern, rather the steps taken involve reporting water use. In many states, agricultural users withdrawing over a threshold volume per specified time frame must now register their water use annually or suffer civil penalty (see the section "Availability and consumption from groundwater or public surface waters by container nurseries will decline significantly in the coming decade").

Agriculture users need to accurately measure and register their water use with state agencies to ensure state governments can develop sound policy governing water quantity allocations among urban, industrial, environmental, and agricultural uses. The ongoing competition between municipalities and agriculture will only become more intense over the next 10 years, especially in regions where water supplies are persistently strained. A disconnect exists between water resource availability and economic development policy.

In North Carolina, all agricultural producers are surveyed annually to determine their withdrawal volumes, but survey compliance is not mandatory (State of North Carolina, 2008). In Florida, water districts work closely with permit applications to determine allocation amounts. In the future, new and existing nurseries, as well as any businesses trying to expand in Florida, may not be granted permits for additional water allocations if the estimated water use in the area of the district where the businesses are located has reached capacity. Permit granting authorities in that area, however, evaluate monthly water use of current permit holders and compare that to historical permitted allocations to ensure all permitted users are withdrawing their full allocation. If the allocation is not reached over a time period or the business no longer needs the allocation, the excess water not withdrawn can be allocated to another permit applicant by the water district, in effect creating a disincentive for water conservation.

Public CONCERN AND LAWS REGARDING THE CONCENTRATIONS OF NUTRIENTS IN PRODUCTION RUNOFF ARE BECOMING MORE WIDESPREAD AND MAY RESTRICT NUTRIENT APPLICATIONS. Between 2008 and 2012 , environmental groups advocating enforcement of the Clean Water Action Plan sued the U.S. Environmental Protection Agency (USEPA) repeatedly (White, 2013). Additional regulations and guidelines surrounding contaminant (predominantly nutrients and sediment) management are being, or have been, enacted. In the eastern United States, regulations [Florida-numeric nutrient criteria (NNC)] and consent decrees [Chesapeake Bay Watershed states - nutrient and sediment total maximum daily loads (TMDLs) ] (Majsztrik and LeaCox, 2013) have been enacted. In California, comprehensive conditional waivers for waste discharge of all contaminants, including mineral nutrients, are available to agricultural producers (California State Water Resources Control Board, 2015); however, Water Quality Control Boards now require water quality monitoring of discharges [irrigation return flow (production runoff), flows from tile drains, and stormwater runoff] by producers to qualify for these waivers. To better insure compliance, many growers have instituted near $100 \%$ containment of production runoff within certain water districts or 
agencies to mitigate potential of production runoff contributing to impairment of monitored surface waters (California State Water Resources Control Board, 2015).

State level regulation and enforcement of TMDLs and NNC is inconsistent because federal, nonpoint source exemptions still govern mitigation requirements for production runoff water. Federal agencies provide oversight, but not funding, to state recommended standards, such as the Chesapeake Bay Watershed Implementation Plans and Florida NNC, which makes monitoring and enforcement a continual debate legislated by each state. In the majority of cases, agrichemical releases from nonpoint source contributors (agricultural production areas) will likely be subject to further regulation, but little monetary support will be available for monitoring or enforcement. Therefore, current implementation of best management practices (BMPs) is under the presumption of compliance because of the combination of poorly funded regulatory enforcement with incomplete validation of current models used to inform environmental load and concentration limit criteria. These factors place the responsibility of environmental stewardship on the grower with very little external motivation or reward for reducing environmental impact.

A complicating factor for nursery crop production systems as related to regulatory compliance is the lack of universal understanding of these systems. Containerized crop production systems, specifically, will likely be subjected to greater regulatory scrutiny because of the nature of where and how container crops are produced (e.g., overhead irrigated, impermeable surfaces, and gravel pads), relegating them to a "quasi-agriculture" status. A current example of this lack of understanding is the approval of only one BMP for voluntary compliance by nursery producers in the Chesapeake Bay watershed area: containment of $95 \%$ of runoff from production areas (acreage) by 2025 (Majsztrik and Lea-Cox, 2013). In California, the Natural Resource Conservation Service partners with Resource Conservation Districts to assist growers with implementation of features (e.g., windbreaks) that increase irrigation efficiency. Another confounding factor is the lack of funding to aid in implementation of BMPs for nursery producers to reduce nonpoint source runoff when compared with incentives available to conventional agriculture. In addition, many growers have enacted BMPs that reduce pollution already, but there is no readily accessible program to receive credit for these benefits comparable to that available for agronomic crops.

ENFORCEMENT OF THE CLEAN WATER ACT WILL CREATE STRICTER GUIDELINES FOR PRODUCTION RUNOFF; THUS INSPIRING MORE EFFICIENT APPLICATION AND TIMING OF WATER APPLICATION AND LESS PRODUCTION RUNOFF, AS WELL AS SPURRING CONSTRUCTION OF STORAGE PONDS FOR THIS WATER. Guidelines for managing production runoff have become stricter in some states simply due to regulation limiting sediment and agrichemical contamination at the watershed scale, discussed briefly above (see the section "Public concern and laws regarding the concentrations of nutrients in production runoff are becoming more widespread and may restrict nutrient applications"). This required a shift from managing effluent from point-source contributors alone, to considering all land uses (e.g., urban, industrial, agricultural, forest, etc.) within a watershed as potential sources of sediment and chemicals that contribute to TMDL or overall nutrient concentration. Both nonpoint and point source contributors will need to effectively reduce agrichemicals and sediment contamination to protect impaired waterways and watersheds. In California, growers have implemented BMPs to comply with legislation and have also pooled resources to comply with monitoring requirements, thus verifying adequate remediation of agrichemicals in production runoff. Innovative growers in many eastern states, when land and resources are available, have now constructed ponds with the intent of increasing water storage. In Florida, use of mRCW requires that it not leave the site even if mixed with other more potable water, therefore, pond construction has increased to use this alternative water source.

On 29 June 2015, the U.S. Army Corps of Engineers (USACE) and USEPA officially published the Clean Water Rule defining the scope of waters considered "Waters of the United States" [WOTUS (USACE and USEPA, 2015)]. The impetus for publishing this new rule was continued confusion over the definition of WOTUS following two supreme court rulings, one in 2001 Solid Waste Agency of Northern Cook County $v$. U.S. Army Corps of Engineers (531 U.S. 159) and the second in 2006 Rapanos v. United States (547 U.S. 715) (Deep and Veasy, 2015). The new rule defines WOTUS to include traditional navigable waters, interstate waters, territorial seas, impoundments of jurisdictional waters, covered tributaries, and covered adjacent waters (USACE and USEPA, 2015). The Clean Water Rule "not only maintains current statutory exemptions, it expands regulatory exclusions from the definition of WOTUS to make it clear that this rule does not add any additional permitting requirements on agriculture" (USACE and USEPA, 2015). Despite this rather clear language regarding agricultural (and thus nursery exemptions), 27 states (as of 13 July 2015) and a coalition of industry groups have filed lawsuits alleging that the USACE and USEPA rule 1) usurps state responsibility for management of certain waters, 2) is too expansive in defining a tributary, and 3 ) violates the Clean Water Act, the National Environmental Policy Act, and the Constitution (Klierly, 2015). The fate of the WOTUS rule is not certain and will be decided by the courts or legislature. Regardless, waters within the United States need to be protected and their quality improved, as $30 \%$ of the streams and rivers and $20 \%$ of the lakes are impaired because of the presence of excessive nitrogen and phosphorus (USEPA, 2010, 2013a). Nursery and greenhouse producers are contributors to contamination in surface waters, and thus efforts should be made to better manage production runoff to protect the WOTUS, regardless of the fate of the most recent clean water rule. There are often numerous difficulties regarding increased grower adoption of pollution control measures including land and labor limitations, financial costs, and possible legal actions that growers weigh before making these types of decisions. State and Federal authorities can pass legislation and provide financial resources to help growers mitigate some of these difficulties. 


\section{Economics}

Cost OF USING MUNICIPAL WATER OR MRCW IS HIGH COMPARED WITH COLLECTION AND PUMPING FROM A WELL OR POND. MRCW WILL BECOME MORE ACCESSIBLE AS A RESULT OF STRICTER ENFORCEMENT OF THE CLEAN WATER ACT AND WILL BECOME A SOURCE OF REVENUE AS DEMAND INCREASES. Wastewater that is used before reentering the natural water cycle may be untreated or treated, which contributes to higher production costs. For many nurseries, the cost of water is largely the cost of operating electric, gas, or diesel pumps. Electric rates increased $\$ 0.0354$ per $\mathrm{kW} \mathrm{h}$ from Aug. 2004 to Aug. 2014, a $27 \%$ increase, which allows pumping from a well, pond, or stream to remain an affordable option (U.S. Energy Information Administration, 2015). Despite increased availability of nonpotable $\mathrm{mRCW}$ in some regions in the United States, the cost for $\mathrm{mRCW}$ remains similar to, if not higher than, typical municipal water sources. This is due, in part, to municipalities existing infrastructure or need for maximizing potable water sales. Treatment costs for mRCW range from $\$ 0.05$ to $\$ 0.13$ per cubic meter (\$0.19 to $\$ 0.49$ per $1000 \mathrm{gal})$ (Asano et al., 2007).

In Irvine, CA, installing dual lines to use recycled water for toilet flushing added $9 \%$ to the cost to plumb buildings seven stories or taller (USEPA, 2013b). When the volume was $100 \mathrm{~m}^{3}(26,417 \mathrm{gal})$ per day or more, a life cycle cost analysis found that mRCW was more cost effective than conventional freshwater or wastewater treated for release (Yamagata et al., 2003). However, as use of $\mathrm{mRCW}$ for irrigation increases or becomes mandatory in some states (southwestern states in particular), potential issues with contaminant residues within mRCW are of concern. Salt and metal-based contaminants could negatively impact plant growth, especially salts contributing to salinity in applied water or water collection and reuse reservoirs. Another unintended consequence could be persistence of organic micropollutants and disinfection by-products in mRCW, with potential deleterious chronic effects to ecosystem health and contamination of groundwater (Calderón-Preciadoa et al., 2011;
Estévez et al., 2012). Growers may need to account for effects of these compounds as well; therefore, their production system could potentially become a tertiary treatment mechanism to help protect and improve water quality. This additional benefit (tertiary treatment of organic micropollutants) should be quantified and in the future used by municipalities to provide economic incentives to agricultural producers assisting in water treatment. In eastern U.S. states, especially in urban and suburban communities where urban sprawl is encroaching on agricultural land, growers have shown interest in using mRCW rather than municipal water sources. However, the economics of infrastructure development preclude their use currently, and likely for the next 10 years, unless dramatic shifts in water availability, regulations regarding water quality, or government incentive programs catalyze investments.

There are no foreseeable ALTERNATIVES TO OVERHEAD IRRIGATION FOR CONTAINER SIZES LESS THAN A NO. 7 CONTAINER. Growers must be able to apply a volume of water to the plant precisely when needed. Overhead irrigation, while economically advantageous from a supply standpoint (i.e., pipes, nozzles, etc.) is inherently inefficient because of space needed between individual plants to allow for uniform growth. Overhead irrigation will remain the most common means by which growers irrigate smaller-sized container crops unless water availability declines to the extent that water conservation is required to stay in business.

In the southeastern United States, there are no widespread, successful examples of using an alternative system of water application to that of overhead sprinklers for container sizes less than a no. 7. Outdoor (uncovered) floriculture and herbaceous perennial production systems are increasingly using drip for irrigation of no. 1 and no. 2 containers for annual crops, [i.e., chrysanthemum (Dendrantbemum $\times$ grandiflora) and pansy (Viola $\times$ wittrockiana)]. Adoption of drip irrigation by these producers may be driven by perceived reductions in disease pressure, lack of consumer tolerance for foliar residues, along with decreasing production inputs for low margin crops.

Capture AND Recycle is THE ONLY ALTERNATIVE TO USING FRESH POTABLE (E.G., GROUND AND SURFACE) WATER FOR IRRIGATION. Recapture and recycling of production runoff by nurseries remains the most viable alternative to that of using potable water especially for production of small container crops. Capture of stormwater, in addition to production runoff, to supplement water supply is limited by region topography, climate, and legislation. The need to increase water recycling and effectively capture rain events will be essential for nurseries in physiographic regions that will experience increasing droughts as a result of global climate change. Moreover, pond design and construction should focus on reducing evaporative losses to save water during storage as well as maximizing phytosanitation, rather than solely focusing on storage capacity. Capturing and reusing water must be part of future water management plans. Ground water withdrawal has significantly increased and is at unsustainable levels (i.e., exceeding the perennial yield) for maintaining water reserves (quantity) or supporting water quality. Nursery growers and agricultural producers together must recognize that water cannot be withdrawn from aquifers substantially faster than it can be recharged and must take action to preserve this resource.

EFFICIENCY OF NURSERY IRRIGATION MUST AND WILL BE INCREASED. In some states (Florida and California), significant strides to increase water use efficiency and conservation have been made in response to regulatory pressure and other drivers. However, in many other states, economic considerations still drive production decisions. Investments in technology that can affect more than one aspect of production (i.e., sensor networks increase irrigation application efficiency, and also decrease production time and disease pressure when managed properly; Chappell et al., 2013) coupled with support from universities bridging the technological gap will likely be the primary mechanisms driving increased irrigation efficiency. At many nurseries in the United States, adoption of low-tech, low-cost options, 
such as installing variable speed pumps to have greater control of water flow; increasing irrigation uniformity; using time clocks; revisiting plant spacing (Million and Yeager, 2015); monitoring soil or substrate water status before irrigating; taking into consideration weather forecasts; and using microirrigation, where appropriate, are a few strategies that could be used by many growers to improve both irrigation application efficiency and water use efficiency. Before adopting a new technology, growers need to first determine the volume of water applied and how evenly it is distributed over the growing area to develop baselines. Then, they can continuously evaluate efficiencies of both water application and interception throughout production cycles. Addressing infrastructure problems that cannot be ameliorated by technology like system leaks, sanitation, incorrect pipe sizes, loose risers, and poor irrigation heads should be the first steps to increase water application and interception efficiency. Both simple solutions and advanced technologies can be found in the Southern Nursery Association's newest version of the Best Management Practices for Nursery Production released in 2013 (Bilderback et al., 2013).

\section{Technology}

DEMAND-BASED IRRIGATION SYSTEMS IRRIGATE PLANTS ONLY AS NEEDED AND WITH THE VOLUME NEEDED. The Federal government and nurseries alike are demonstrating their support for demand-based irrigation system technologies, with $\approx 47 \%$ of USDA-National Institute of Food and Agriculture (NIFA) Specialty Crops Research Initiative funding awarded to date for nursery and greenhouse crops supporting research and extension projects that include moisture sensors and evapotranspiration based models, other irrigation technology and intellectual property to aid in containing and reusing water, and investigating how changes in basic production inputs (e.g., container type) may affect water use.

The California Energy Commission, jointly with the Department of Water Resources and the State Water Resources Control Board, will implement a Water Energy Technology program to deploy innovative water management technologies for businesses, residents, industries, and agriculture. This program aims to achieve water and energy savings and greenhouse gas reductions by accelerating use of cutting-edge technologies such as renewable energy-powered desalination, integrated on-site reuse systems, water-use monitoring software, irrigation system timing and precision technology, and on-farm precision technology (State of California, 2015). Water use for irrigation has dramatically decreased in other specialty crops as a result of targeted water applications. For example, Paramount Farms, California's largest agricultural water user, invested \$25 million in almond (Prunus dulcis) and pistachio (Pistacia vera) irrigation research to reduce their water consumption (Hall, 2014). However, water use has not declined for nursery crops, especially container production as discussed in the section "Availability and consumption from groundwater or public surface waters by container nurseries will decline significantly in the coming decade." Irrigation scheduling is only a part of the solution and cannot compensate for large inefficiencies in the delivery system.

\section{Political}

INDUSTRY ADVOCACY WILL FOCUS ON SOFTENING THE IMPACT OF WATER RESTRICTIONS TO PREVENT FARREACHING LEGISLATION. Over the past 10 years, restrictions and legislation relating to allocation and management of water by nurseries have been minimal. However, competition among water consumers and policy decisions related to these conflicts will only increase over the coming decade. Increasing competition will be exacerbated by an apparent trend toward extreme weather patterns and potential for extended droughts, which simultaneously impacts plant production by reducing the water supply and increasing the demand for water because of the concomitant higher temperatures in summer and lack of rainfall. Demonstrated commitment to protecting water resources by adopting BMPs is still perceived to reduce the risk of sweeping and draconian legislation or regulation.

As economic recovery continues, the pace of residential and industrial development will hasten, further straining water resources and allocations. Water laws surrounding quantity and quality will continue to be contentious issues that may even supersede labor in importance. In states like California and Florida, where agriculture has a strong presence and is politically influential, organized agricultural commodity groups may be better able to negotiate and help shape policy. Economic development has a political stature that is not always commensurate with water resource availability or quality. In many instances, states vying for new industry do not consider water resource quality or quantity in economic decisions; e.g., Tesla Motors (Palo Alto, CA) battery "giga factory," an intensive water user, courted by Texas (Morain, 2014) during a drought in which $46 \%$ of the state was in a D3 (extreme) or D4 (exceptional) drought category (U.S. Drought Monitor, 2014). Traditional municipal water management strategies are no longer sufficient. A nationally coordinated approach, accounting for water resource capacity and current allocations within multistate watersheds, may be needed to support economic development in concert with water sustainability and preservation.

\section{Assessment of past predictions \\ Reflecting on the past 10 years}

CONTAINER NURSERY IRRIGATION WILL BE FORCED TO BECOME MORE EFFICIENT AND WATER CONSERVING IN THE COMING DECADE. In general, producers have not adopted more efficient and water conserving practices unless an economic incentive or legal imperative (return on investment or potential for regulation and/or fines) motivated the decision. For example, growers in Florida that enroll in the Florida Department of Agriculture and Consumer Services BMP Program and implement approved BMPs can maintain "a presumption of compliance with state water quality standards for the pollutants addressed by the BMPs" and are also eligible for cost share for certain BMPs (Florida Department of Agriculture and Consumer Services, 2014). In many states within the Chesapeake Bay Watershed, compliance to meet consent decree nutrient limits remains voluntary, yet progress to meet the goals must be achieved between 2017 and 2025 . In New Jersey, some nurseries are 
implementing changes in irrigation methodology and containment practices to minimize runoff and ensure capture of remaining irrigation runoff water in anticipation of the New Jersey Department of Environmental Protection imposing a deadline for requiring containment of all production runoff (DeVincentis et al., 2014). Growers in Tennessee, through a NIFA-sponsored initiative, are receiving subsidized water conserving technology, consultation, and education as an incentive to adopt waterconserving practices. However, these programs are the exception, not the norm, and except where persistent water scarcity exists, nurseries have not widely adopted water-conserving measures.

\section{Projections of the coming decade (2015 to 2025)}

EVEN IF SOLUTIONS TO CONSERVE WATER ARE AVAILABLE, THEY WILL NOT BE BROADLY ADOPTED UNTIL WATER QUANTITY OR QUALITY HAS AN IMMEDIATE NEGATIVE ECONOMIC IMPACT OR ACCESS TO WATER IS THREATENED THROUGH LITIGATION, CHANGES IN REgULATIONS, OR Climate. ONLY THEN Will R E S E A R C H - B A S E D W A T E R CONSERVATION PRACTICES BE SOUGHT ON A WIDESPREAD BASIS. Resource management, crop production practices, and environmental stewardship will persist in their current state for most parts of the United States; however, there will be regions within the United States where resources become limited, environmental issues arise or worsen, and progressive city planners design or install landscapes to provide ecosystem services in addition to pleasing aesthetics. Regions with limited resources will be population centers that were developed in resource deficit locations originally, with aging infrastructure, or both. Contamination of potable water resources will be an increasingly prominent issue. Moreover, greenhouses and nurseries, as a highly visible part of agriculture, will be identified as high water consumers and more strongly as nonpoint source contributors that may degrade water quality in impaired waterways. This newfound notoriety will necessitate implementation of new BMPs or further scientific justification of established BMPs. For now, BMP implementation is a proxy for oversight or regulation of compliance as defined by states to meet Clean Water Act standards. Agriculture may lose some of the current, state specific exemptions that preclude it from responsibility for some environmental laws. For example, the Chesapeake Bay, Everglades, and Lake Erie recently experienced oversight through local, state, or national government agencies. In the next decade, water use will be more closely monitored, if not regulated, in riparian water rights states in the eastern United States. To reduce water withdrawals from surface and groundwater supplies and to decrease nutrients and pesticides in runoff, irrigation water (and nutrients and pesticides) must be applied more precisely using technology to schedule irrigation. Currently, there are numerous models to schedule irrigation that range from basic tests of physically measuring crop water application efficiency regularly to integrating current weather, crop, and soil or substrate water status. $\mathrm{Al}$ though these technologies remain in their adolescence, they will mature to something more robust, user friendly, and less expensive, perhaps using similar technologies from other industries and will become commonplace in nurseries and greenhouses of the future. Currently, technologies are being evaluated and refined by onfarm assessments with innovative crop producers connected with university scientists via grants or industry partnerships. In time, early adopters, followed by the early majority of nursery growers watching closely, will begin to implement these newer technologies (Bohlen et al., 1960). Use of technology to refine nursery inputs will become more market driven as adopters realize economic savings because of more refined use of water, nutrients, and pesticides. Moreover, employees from more recent generations will want to use technologies that can provide real-time information and that can be used to aid in decision-making or to automate processes such as irrigation scheduling. Conservation of water is the goal from an environmental and social perspective, whereas improved plant quality with fewer inputs is a beneficial outcome from a grower's perspective. However, in some states producers are subject to a "use or lose" disincentive for water conservation. Growers who adopt progressive water management practices that reduce total water use, but do not expand production or otherwise use the "saved" water are vulnerable to losing that portion of their water allocation.

Within regions where resource scarcity is challenged further by increases in population and urbanization, water for human and economic sustenance will begin to take precedence. Water scarcity will be realized first in population centers and regions where groundwater is not abundant or diminishing and where changing climate alters the periodicity of water availability; this will result in evaluation of the historical methodology of water distribution or allocation. Changes in water appropriations will first occur to ensure adequate quantity and quality for population centers to sustain or increase urbanization and development. In addition, residential and commercial water use guidelines legislated for times of drought within cities and suburbia may become modified for water use in nondrought times. Fewer permits for wells will be issued, thus limiting the increase in use of groundwater while increasing reliance on capturing and reusing water. These events might stimulate investment in mRCW. Shifts in awareness and behavior occur during every drought, and inevitably legislation passes that may abruptly move current thinking toward conservation of the resource. After droughts pass, behavior may slide back to less conservative trends; however, the legislation passed provides some incentive to continue to conserve water, or at least provides a clearer definition of water use in agriculture and urban areas.

The real cost of water will begin to be realized and monetized, defining the product carrying capacity for a given nursery or production land area. The volume of water needed to operate each year can no longer be estimated or unknown by growers, but rather must be well defined and documented so as to be defendable if challenged. Growers cannot afford to operate on the assumption that water rights will persist unaltered throughout the next decade. Eventually, water allocation will be further complicated by preparation for 
relocation or protection of urban and city centers from inevitable sea level rise, which will impact real estate, land availability, and access to high quality potable water. This in turn may result in closure or relocation of nurseries to ensure they have affordable land and access to quality water and remain viable in a new market driven by new concerns of the local and regional ecosystem.

In the future, the link between water and energy will be more pronounced. For example, currently in California, $19 \%$ of electrical use and $30 \%$ of natural gas use is due to intrastate water movement as well as treating water (Copeland, 2014; Klein et al., 2005). According to a 2009 report (Griffiths-Sattenspiel and Wilson, 2009), the energetic costs of moving, treating, and heating water in the United States account for $290 \mathrm{t}$ of carbon dioxide emission per year, or $5 \%$ of U.S. carbon emissions. The energy savings and associated carbon emission reduction correlated with water savings will become increasingly important factors in water use, allocation, and conservation decisions.

The plant palette produced will change to better address water quality and availability issues within cities and urban areas, as well as address awareness of the environment by current and future generations. This societal awareness will aid horticultural producers in sales of plants that provide design aesthetics along with function. Plants will be used to provide ecosystem services (clean air and water), health benefits (physical and emotional), energy savings (mitigation of heat island effects), stormwater control, economic development (revitalization of urban centers, home values) and, in part, provide food for homes and communities. There will be increasing need for plants that are low maintenance, drought tolerant, salt tolerant, and provide the aforementioned socioecological functions.

\section{Literature cited}

Asano, T., F.L. Burton, H. Leverenz, R. Tsuchihashi, and G. Tchobanoglous. 2007. Water reuse: Issues, technologies and applications. McGraw-Hill, New York, NY.

Beeson, R.C., M.A. Arnold, T.E. Bilderback, B. Bolusky, S. Chandler, H.M. Gramling,
J.D. Lea-Cox, J.R. Harris, P.J. Klinger, H.M. Mathers, J.M. Ruter, and T.H. Yeager. 2004. Strategic vision of container nursery irrigation in the next ten years. J. Environ. Hort. 22:113-115.

Belayneh, B.E., J.D. Lea-Cox, and E. Lichtenberg. 2013. Cost and benefits of implementing sensor-controlled irrigation in a commercial pot-in-pot nursery. HortTechnology 23:760-769.

Bilderback, T., C. Boyer, M. Chappell, G. Fain, D. Fare, C. Gilliam, B.E. Jackson, J. Lea-Cox, A.V. LeBude, A. Niemiera, J. Owen, J. Ruter, K. Tilt, S. Warren, S. White, T. Whitewell, R. Wright, and T. Yeager. 2013. Best management practices: Guide for producing nursery crops. 3rd ed. Southern Nursery Association, Acworth, GA.

Bohlen, J., C.M. Coughenour, H.F. Lionberger, E.O. Moe, and E.M. Rogers. 1960. Adopters of new farm ideas: Characteristics and communication behavior. North Central Reg. Ext. Publ. No. 13. 26 Nov. 2015. <http://www.soc.iastate. edu/extension/pub/comm/NCRl3 $\mathrm{pdf}>$.

Calderón-Preciadoa, D., C. JiménezCartagena, V. Matamorosc, and J.M. Bayona. 2011. Screening of 47 organic microcontaminants in agricultural irrigation waters and their soil loading. Water Res. 45:221-231.

California State Water Resources Control Board. 2015. Irrigated lands regulatory program. 23 Oct. 2015. <http://www. swrcb.ca.gov/water_issues/programs/ agriculture/docs/about_agwaivers.pdf $>$.

Chappell, M., S.K. Dove, M.W. van Iersel, P.A. Thomas, and J. Ruter. 2013. Implementation of wireless sensor networks for irrigation control in three container nurseries. HortTechnology 23:747-753.

Commonwealth of Virginia. 2015. Water withdrawal reporting regulation, chapter 200. 23 Oct. 2015. <http://lis.virginia. g o v / $000 / \mathrm{reg} / \mathrm{T}$ O C 09025 . HTM\#C0200>.

Copeland, C. 2014. Energy-water nexus: The water sector's energy use. Congressional Research Service. Report R43200. 14 Jan. 2016. <https://www.fas.org/ $\mathrm{sgp} / \mathrm{crs} / \mathrm{misc} / \mathrm{R} 43200 . \mathrm{pdf}>$.

Deep, D.J. and P.F. Veasy. 2015. EPA attempts to clarify "Waters of the United States". 26 Nov. 2015. <http://www. natlawreview.com/article/epa-attemptsto-clarify-waters-united-states $>$.

DeVincentis, A., R. Brumfield, and P. Gottlieb. 2014. A step ahead. 23 Oct. 2015. <http://www.greenhousemag. com/nm0914-water-recycling-system. aspx>.
Estévez, E., M. del Carmen Cabrera, A. Molina-Díaz, J. Robles-Molina, and M. del Pino Palacios-Díaz. 2012. Screening of emerging contaminants and priority substances $(2008 / 105 / E C)$ in reclaimed water for irrigation and groundwater in a volcanic aquifer (Gran Canaria, Canary Islands, Spain). Sci. Total Environ. 433:538-546.

Feinstein, D.T., R.J. Hunt, and H.W. Reeves. 2010. Regional groundwaterflow model of the Lake Michigan Basin in support of Great Lakes Basin water availability and use studies. U.S. Geological Survey, Scientific Investigation Rpt. 2010-5109. 23 Oct. 2015. <http:// pubs.usgs.gov/sir/2010/5109/>.

Fernandez, R.T. 2014. The future of water quality. Amer. Nurseryman. 2014 (June):18-21.

Florida Department of Agriculture and Consumer Services. 2014. Water quality/ quantity best management practices for Florida nurseries. 23 Oct. 2015. <http:// www.freshfromflorida.com/content/ download/37570/848371/NurseryBMP. pdf>.

Georgia Department of Natural Resources. 2011. Georgia's water future in focus: Highlights of regional water planning 2009-2011. 23 Oct. 2015. <http:// www.georgiawaterplanning.org/ documents/Highlights_of_Regional_ Water_Planning.pdf>.

Griffiths-Satttenspiel, B. and W. Wilson. 2009. The carbon footprint of water. 14 Jan. 2016. <https://www.rivernetwork. org/wp-content/uploads/2015/10/ The-Carbon-Footprint-of-Water-RiverNetwork-2009.pdf $>$.

Guo, J. 2015. Agriculture is 80 percent of water use in California. Why aren't farmers being forced to cut back? 23 Oct. 2015. <http://www.washingtonpost. com/blogs/govbeat/wp/2015/04/ $03 /$ agriculture-is- 80 -percent-of-wateruse-in-california-why-arent-farmersbeing-forced-to-cut-back $/>$.

Hall, C. 2014. Water: Horticulture's next game changer? Findings from the 2014 Seeley Summit. 12 Jan. 2016. <http:// americanhort.theknowledgecenter.com/ American Hort News / index.cfm? view $=$ detail $\&$ colid $=147 \& \mathrm{cid}=1444 \&$ $\mathrm{mid}=7164$ \& C F I D =3023324 \& CFTOKEN $=5659$ a bc 9 b 0 ce 80 $31 \mathrm{~A} 2 \mathrm{C} 98 \mathrm{D}-\mathrm{F} 2 \mathrm{~B} \mathrm{E}-40 \mathrm{~F} 7$ B307D4C1CA13176B>.

Hilton Head Public Service District. 2014. Saltwater intrusion. 26 Nov. 2015. <http://www.hhpsd.com/?page_ $\mathrm{id}=42 \mathrm{l}>$.

Hodges, A.W., H. Khachatryan, C.R. Hall, and M.A. Palma. 2015. Production 
and marketing practices and trade flows in the United States green industry, 2013. Southern Coop. Ser. Bul. No. 420.

Hong, C., G.W. Moorman, W. Wohanka, and C. Buttner. 2014. Biology, detection, and management of plant pathogens in irrigation water. APS Press, St. Paul, MN.

Howitt, R.E., J. Medellin-Azuara, D. MacEwan, J.R. Lund, and D.A. Sumner. 2014. Economic analysis of the 2014 drought for California agriculture. 23 Oct. 2015. <https://watershed.ucdavis. edu/>.

Intergovernmental Panel on Climate Change. 2013. Technical summary, p. 33-1 18. In: T.F. Stocker, D. Qin, G.-K. Plattner, M. Tignor, S.K. Allen, J. Boschung, A. Nauels, Y. Xia, V. Bex, and P.M. Midgley (eds.). Climate change 2013: The physical science basis. Contribution of working group I to the fifth assessment report of the intergovernmental panel on climate change. Cambridge Univ. Press, Cambridge, UK/New York, NY.

Johnson, B. 2013. Salinas Valley farmers tackle seawater intrusion. 11 Jan. 2016. $<$ http://www.agalert.com/story/? id $=5421>$.

Kenny, J.F., N.L. Barber, S.S. Hutson, K.S. Linsey, J.K. Lovelace, and M.A. Maupin. 2009. Estimated use of water in the United States in 2005. U.S. Geol. Surv. Circ. 1344.

Klein, G., M. Krebs, V. Hall, T. O’Brien, and B. Blevins. 2005. California's waterenergy relationship. California Energy Commission CEC-700-2005-011-SF. 11 Jan. 2015. <http://www.energy.ca.gov/ 2005publications/CEC-700-2005-011/ CEC-700-2005-011-SF.PDF>.

Klierly, S. 2015. It's raining WOTUS lawsuits. 23 Oct. 2015. <http://www. hpj.com/opinion/it-s-raining-wotuslawsuits/article_3cbc8f5b-fde0-5389b94c-7dal $826825 \mathrm{f} 8$.html>.

LeBude, A.V. and T.E. Bilderback. 2007. Managing drought on nursery crops. North Carolina Coop. Ext. Publ. AG519-6. 26 Nov. 2015. <http://content. ces.ncsu.edu/managing-drought-onnursery-crops- $1 />$.

Loyd, A.L., D.M. Benson, and K.L. Ivors. 2014. Phytophthora populations in nursery irrigation water in relationship to pathogenicity and infection frequency of Rhododendron and Pieris. Plant Dis. 98:1213-1220.

Majsztrik, J.C. and J.D. Lea-Cox. 2013. Water quality regulations in the Chesapeake Bay: Working to more precisely estimate nutrient loading rates and incentivized best management practices in the nursery and greenhouse industry. HortScience 48:1097-1102.

Majsztrik, J., E. Lichtenburg, and M. Saavos. 2013. Ornamental grower perceptions of wireless irrigation sensor networks: Results from a national survey. HortTechnology 23:775-782.

Maupin, M.A., J.F. Kenny, S.S. Hutson, J.K. Lovelace, N.L. Barber, and K.S. Linsey. 2014. Estimated use of water in the United States in 2010. U.S. Geological Survey Circ. 1405. 26 Nov. 2015. <http://dx.doi.org/10.3133/cir1405>.

Million, J.B. and T.H. Yeager. 2015. Capture of sprinkler irrigation water by container-grown ornamental plants. HortScience 50:442-446.

Morain, D. 2014. Texas Gov. Rick Perry makes a play for Tesla's battery factory. 26 Nov. 2015. <http://www.sacbee.com/ opinion/opn-columns-blogs/danmorain/article2601328.html>.

Omahen, S. 2008. Green industry's profits, production withering. $13 \mathrm{Feb}$. 2008. <http://www.earlycountynews. com/news/2008-02-13/agriculture/ 053.html>.

Ouellet, K. 2014. Drought-tolerant popularity calls for due diligence. 23 Oct. 2015. <http://www.greenhousemag. com/article/gm0414-drought-tolerantplants-demand $>$.

Parsons, L.R., B. Sheikh, R. Holden, and D.W. York. 2010. Reclaimed water as an alternative water source for crop irrigation. HortScience 45:1626-1629.

Raudales, R.E., J.L. Parke, C.L. Guy, and P.R. Fisher. 2014. Control of waterborne microbes in irrigation: A review. Agr. Water Mgt. 143:9-28.

Reid, A. 2011. South Florida drinking water faces saltwater threat. $12 \mathrm{Sept}$. 2011. <http://articles.sun-sentinel. com/2011-09-12/health/fl-saltwaterintrusion-20110912_1_saltwaterintrusion-saltwater-threat-drinking-water>.

Sbranti, J.N. 2014. Jump in well permits in Stanislaus County triggers calls for moratorium. 26 Nov. 2015. <http:// www.modbee.com/news/special-reports/ groundwater-crisis/article3163963.html .

State of California. 2014a. Governor Brown signs historic groundwater legis lation. 23 Nov. 2015. <http://gov.ca. gov/news.php? id=18701 $>$.

State of California. 2014b. Senate Bill 1168. Groundwater management to amend the water code. 22 Nov. 2015. <http://leginfo.legislature.ca.gov/ faces / bill NavClient.xhtml? bill id $=201320140$ SB $1168>$.
State of California. 2015. Executive Order B-29-15. 24 Nov. 2015. <https:// www.gov.ca.gov/docs/4.1.15 Executive_Order.pdf $>$.

State of Georgia. 2014. Development of possible new drought management rules. 23 Oct. 2015. <http://epd.georgia.gov/ development-possible-new-droughtmanagement-rules $>$.

State of Michigan. 2003. Public Act 148. 23 Oct. 2015. <http://www.legislature. mi.gov/documents /2003-2004/ publicact $/ \mathrm{htm} / 2003-\mathrm{PA}-0148$.htm $>$.

State of Michigan. 2006. Public Act 35. 23 Oct. 2015. <http://www.legislature. mi.gov/documents/2005-2006/ publicact $/ \mathrm{htm} / 2006-\mathrm{PA}-0035$.htm $>$.

State of North Carolina. 2008. An act to improve drought preparedness and response in North Carolina. SL 2008-143. 23 Oct. 2015. <http://www.ncleg.net/ Sessions /2007/Bills/House/PDF/ H2499v6.pdf>.

State of South Carolina. 2014. South Carolina Code of Laws, Title 49, Chapter 4. Surface water withdrawal, permitting, use, and reporting act. 23 Oct. 2015. $<$ ht p://www.s cdhec.gov/ environment/WaterQuality / Surface WaterWithdrawals/ SurfaceWaterOverview/>

State of Tennessee. 2015. Tennessee Codes and Statutes, Title 69. Waters, waterways, drains and levees. 24 Nov. 2015. <http://www.lexisnexis.com/ hottopics/tncode/>.

Taylor, D.L. 2014. Pajaro Valley plan targets seawater intrusion. 30 Aug. 2014. <http://archive.thecalifornian.com/ article/20140305/NEWS0l/ $303050010 /$ Pajaro-Valley-plan-targetsseawater-intrusion $>$.

Thomas, P. and C. Hall. 2010. Know your costs. 12 Jan. 2016 . <https://www. nurserymag.com/article/nmpro-1010know-your-costs-operationalbenchmarking $>$.

U.S. Army Corps of Engineers and U.S. Environmental Protection Agency (USACE and USEPA). 2015. Clean water rule: Definition of "Waters of the United States." Federal Register. Doc. 201513435. 80(124):370541-37127.

U.S. Census Bureau. 2012. National population projections. 2012 national population projections: Projections of the population and components of change for the United States: 2015 to 2060. 26 Nov. 2015. <http://www.census.gov/ population/projections/data/national/ 2012.html .

U.S. Department of Agriculture. 2014. Tables 5, 41, and 43. 2013 Farm and 


\section{Features}

ranch irrigation survey. U.S. Department of Agriculture, Washington, DC.

U.S. Drought Monitor. 2014. U.S. Drought Monitor classification scheme. 26 Nov. 2015. <http://droughtmonitor.unl. edu/AboutUs/ClassificationScheme. aspx $>$.

U.S. Drought Monitor. 2015. U.S. Drought Monitor statistics graph. 23 Oct. 2015. <http://droughtmonitor.unl. edu/MapsAndData/Graph.aspx>.

U.S. Energy Information Administration. 2015. Short-term energy outlook. 11 Jan. 2016. <https://www.eia.gov/forecasts/ steo/realprices/>.

U.S. Environmental Protection Agency. 2010. National lakes assessment factsheet.
EPA 84l-F-09-007. U.S. Environ. Protection Agency, Washington, DC.

U.S. Environmental Protection Agency. 2013a. The national rivers and streams assessment 2008-2009: A collaborative survey. EPA 841-F-13-004. U.S. Environ. Protection Agency, Washington, DC.

U.S. Environmental Protection Agency. $2013 \mathrm{~b}$. Water availability and variability strategies for public water systems. EPA 816-F-13-005. U.S. Environ. Protection Agency, Washington, DC.

Wallander, S. and M.S. Hand. 2011. Measuring the impact of the environmental quality incentives program (EQIP) on irrigation efficiency and water conservation. Agr. Appl. Econ. Assn. Proc. Paper 103269.

White, S.A. 2013. Regulating water quality: Current legislation, future impacts: Introduction to the colloquium. HortScience 48:1095-1096.

Yamagata, H., M. Ogoshi, Y. Suzuki, M. Ozaki, and T. Asano. 2003. On-site water recycling systems in Japan. Water Sci. Technol. Water Supply 3:149-154.

Yeary, W., A. Fulcher, and B. Leib. 2014. Results of nursery drought preparedness inventory. 12 Jan. 2016. <http:// plantsciences.utk.edu/pdf/fulcher results_nurserycrop_drought_and_ preparedness_inventory.pdf>. 